\title{
Detection of Gelatinolytic Activity in Deciduous Sound Dentin
}

\author{
Sağlam Süt Dişi Dentininde Jelatinolitik Aktivite Tespiti \\ Berdan AYDIN ${ }^{1,2 *}$
}

IUniversity of Illinois at Chicago, College of Dentistry, Restorative Dentistry, Chicago/IL, USA.

${ }^{2}$ RAKCODS (Ras al Khaimah College of Dentistry) Department of Operative Dentistry and Endodontics, RAK/United Arab Emirates Orcid: 0000-0003-3317-1095

Atıf/Citation: Aydın, B. (2020). Detection of Gelatinolytic Activity in Deciduous Sound Dentin. Ege Üniversitesi Diş Hekimliği Fakültesi Dergisi, 41(1), 55-60.

\begin{abstract}
INTRODUCTION: The purpose of present study was to demonstrate the intrinsic gelatinolytic activty in sound dentin of primary teeth by detecting and stimulating the activity of these enzymes.

METHODS: Sound dentin from 19 extracted primary teeth were collected and cryo-pulverized into a fine powder. Fluorescein conjugate-gelatin DQ Gelatin EnzCheck gelatinase/collagenase kit (Molecular Probes, Eugene, OR, USA) was used as the cleavage substrate. Intrinsic gelatinolytic enzymes were activated by treating sound dentin powder with 4-Aminophenylmercuric acetate (4-APMA, Sigma-Aldrich International $\mathrm{GmbH}$ ). A full day (24 h) continuous record of fluorescence emission intensity (FEI) was targeted at $535 \mathrm{~nm}$ using 96-well plate reader spectrophotometer (Victor 5 Multilabel Plate Reader, PerkinElmer Life Sciences, Boston, MA, USA).
\end{abstract}

RESULTS: Gelatinolytic activity was detected in sound dentin of primary teeth $(981,59 \pm 115)$ and 4-APMA treated dentin exhibited higher gelatinolytic activity (1961,78 \pm 204$), p<0,05$.

DISCUSSION AND CONCLUSION: Gelatinolytic enzymes are present in sound dentin of primary teeth and their activity is enhanced with 4-APMA. So, sound deciduous dentin possesses gelatinolytic enzymes which may lead to self-destruction if exposed to conditions that induce theiractivation.

Keywords: deciduous tooth, dentin, enzyme activity, 4-APMA, primary tooth

ÖZ

GiRIŞ ve AMAÇ: Bu çalışmanın amacı süt dişlerine ait dentin dokusundaki intrinsik jelatinolitik aktivitenin direkt olarak ve aktivitesinin uyarılarak artırılıp saptanmasıdır.

YÖNTEM ve GEREÇLER: On dokuz adet süt dişinden elde edilen sağlam dentin dondurulup pulverize edilerek ince bir toz haline getirilmiştir. Floresin bağlanmış jelatin DQ (Gelatin EnzCheck gelatinase/collagenase kit, Molecular Probes, Eugene, OR, $A B D$ ) jelatinolitik enzim substratı olarak kullanılmıştır. Intrinsik jelatinolitik enzim aktivitesi 4Aminophenylmercuric acetate (4-APMA, Sigma-Aldrich International GmbH) kullanılarak aktive edilmiştir. 96”lı mikropetri içerisine koyulan örneklerin floresans emisyon miktarı (FEI), $535 \mathrm{~nm}$ eksitasyonda 24 saat boyunca petri okuyucu spektrofotometre ile kaydedilmiştir (Victor 5 Multilabel Plate Reader, PerkinElmer Life Sciences, Boston, MA, USA).

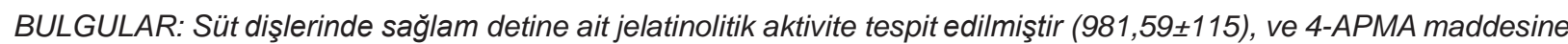
maruz kalan dentin istatistiksel olarak daha fazla jelatinolitik aktivite göstermiştir $(1961,78 \pm 204),(p<0,05)$.

TARTIŞMA ve SONUÇ: Jelatinolitik enzimler süt dişleri dentininde mevcuttur ve 4-APMA ile aktiviteleri artırılabilmektedir. Yani, jelatinolitik enzimlerin etkinliklerini artıracak bir durumda dentin dokusunda yıkım oluşması muhtemeldir.

Anahtar Kelimeler: süt dişleri, dentin, enzim aktivitesi, 4-APMA

Sorumlu yazar/Corresponding author*:

berdansevinc@gmail.com

Başvuru Tarihi/Received Date: 18.11.2019

Kabul Tarihi/Accepted Date: 28.01.2020 


\section{INTRODUCTION}

As early as 1949s acid producing bacteria were reported to be responsible for the aggravation of caries. ${ }^{1-3}$ Later, the mechanism of caries aggravation was understood better since the acid producing cariogenic bacteria was shown to degrade the inorganic portion of dentin ${ }^{4}$ leading to the exposure of the organic collagen matrix $^{5}$. Also, intrinsic proteolytic and gelatinolytic enzymes, mostly matrix metalloproteinases (MMPs) located in permanent dentin are activated in acidic environment, which in turn contribute to the breakdown of its organic matrix. ${ }^{6-8}$

It was shown that cariogenic bacteria are not capable to cleave dentin matrix sufficiently to result in a cavity formation. ${ }^{6-9}$ Instead, intrinsic proteolytic and gelatinolytic activity of host enzymes are responsible for the degradation of the organic matrix during the caries progression. ${ }^{10,11}$ Type of these enzymes and their sitespecific and function-related properties are already welldocumented for permanent dentin. ${ }^{12-17}$ Tooth caries is the most prevalent chronic disease in children ${ }^{18}$; yet, given the fact that such destructive intrinsic enzyme activity has not been directly shown in sound deciduous dentin. The objective of this study was to investigate the gelatinolytic activity in primary teeth dentin. The null hypotheses tested were that there is no gelatinolytic activity in deciduous dentin and gelatinolytic activity is not enhanced when a MMP activator 4-Aminophenylmercuric acetate (4APMA) is used.

\section{MATERIALS AND METHODS}

Primary teeth $(\mathrm{N}=19)$ were extracted due to mobility associated with root resorption in the surgery and pediatric dentistry departments at UIC. The teeth were placed in a container with $\mathrm{CO}_{2}$ ice and kept frozen until use. Present research proposal was approved by the institutional review board of the University of Illinois at Chicago, which is complied with the principles of Declaration of Helsinki with a year and an approval number of "\#20150453". Consent forms were signed by the parents or the parents with Child Foster care or legal guardianship. Collected teeth were inspected in terms of the presence of dentin caries, and teeth with caries were excluded before cutting off dentin. The sound dentin was obtained using the primary tooth crowns after removing enamel with diamond burs connected to high-speed handpiece under copious water irrigation, and cryo-pulverized further using the device CryoMill (Retsch GmbH, Retsch-Allee 1-5, 42781 Haan, Germany) into a fine powder. Next, dentin powder was demineralized using $10 \%$ phosphoric acid for five hours, followed by five times rinse in water using a centrifuge. ${ }^{17}$ After accomplishing lyophilization dry weigth was measured to be around $250 \mathrm{mg}$, and dentin powder was stored at $-20^{\circ} \mathrm{C}$.

The experimental groups and workflow were explained in Figure 1, included assessment of gelatinolytic activity of sound dentin as well as its exposure to 4APMA. Fluorescein conjugated gelatin (DQ gelatin, EnzCheck gelatinase/collagenase kit) was used as the cleavage substrate. A reaction buffer was created for the optimal enzyme activity: $50 \mathrm{~mL}$ of $0,5 \mathrm{M}$ Tris- $\mathrm{HCl}, 1,5$ $\mathrm{M} \mathrm{NaCl}, 50 \mathrm{mM} \mathrm{CaCl}, 2 \mathrm{mM}$ Sodium Azide, $\mathrm{pH}$ 7,4. First an addition of $\mathrm{g}^{2} \mu \mathrm{L}$ reaction buffer to the wells were performed using black 96-well plates (generic $8 \times 12$ size). Next, $20 \mu \mathrm{L}$ DQ solution $(1,0 \mathrm{mg} / \mathrm{mL})$ was added to the wells; since, DQ gelatin concentrations fall between 12,5-100 $\mu \mathrm{g} / \mathrm{mL}$ were resulted in tractable enzyme-substrate interactions in our pilot trials and in previously published studies. ${ }^{16}$ As an external control, a stock solution of Clostridium collagenase (Collagenase, Type IV from Clostridium histolyticum, Sigma-Aldrich International GmbH) prepared to be $1000 \mathrm{U} / \mathrm{mL} .100 \mu \mathrm{L}$ of the Clostridium collagenase enzyme solution (positive control), or $100 \mu \mathrm{L}$ of reaction buffer was dispersed into the wells (negative control).

Final volume in wells is $200 \mu \mathrm{L}$, and the groups were designed as follows:

Negative control: $80 \mu \mathrm{L}$ buffer, $20 \mathrm{DQ} \mu \mathrm{L}$ gelatin, $100 \mu \mathrm{L}$ buffer. Positive control: $80 \mu \mathrm{L}$ buffer, $20 \mathrm{DQ}$ $\mu \mathrm{L}$ gelatin, $100 \mu \mathrm{L}$ enzyme solution of Clostridium collagenase dissolved in same reaction buffer. Intrinsic gelatinolytic activity of sound dentin:80 $\mu \mathrm{L}$ buffer, $20 \mu \mathrm{L}$ DQ gelatin, $90 \mu \mathrm{L}$ buffer, $10 \mu \mathrm{L}$ suspension of sound dentin powder treated with $\mathrm{pH} \quad 7,4$ distilled water only. 4-APMA stimulated intrinsic gelatinolytic activity of sound dentin: Based on the previous studies' methodology to stimulate gelatinolytic enzymes ${ }^{12,19} 2$ $\mathrm{mM}$ final concentration of 4-APMA (Sigma-Aldrich International $\mathrm{GmbH})$ in wells $(0,4 \mu \mathrm{L}$ 4-APMA from the stock solution of $1 \mathrm{M}$ was placed into each well). $80 \mu \mathrm{L}$ buffer, $20 \mu \mathrm{L}$ DQ gelatin, $90 \mu \mathrm{L}$ buffer, $10 \mu \mathrm{L}$ suspension of sound dentin powder.

Primary dentin powder was treated with deionized water $(\mathrm{pH} 7,4)$ for 3 minutes, followed by rinsing, 


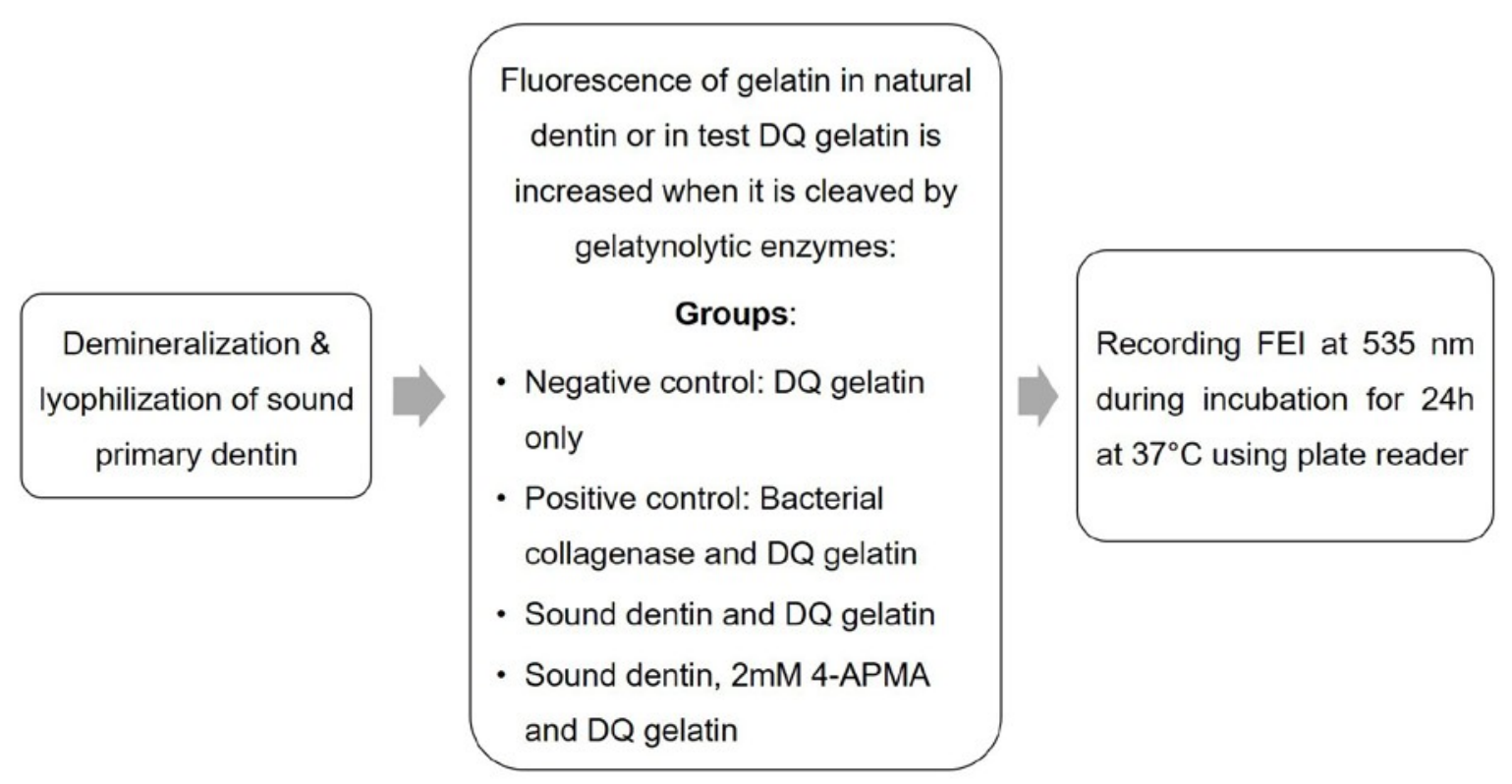

Figure-1 The experimental groups and workflow were explained.

centrifuging and re-suspending in the reaction buffer. A total of $10 \mu \mathrm{L}$ of the suspended powder was used in triplicate in reaction buffer either with or without a $2 \mathrm{mM}$ 4-APMA. The samples were incubated at $37^{\circ} \mathrm{C}$ in a 96 well plate and fluorescence emission intensity (FEI) was recorded continuously at $535 \mathrm{~nm}$ every hour for 24 hours using a spectrophotometer (Victor 5 Multilabel Plate Reader, PerkinElmer Life Sciences, Boston, MA, USA). For each time point, corrections were done automatically for the background fluorescence by subtracting thevalue derived from the readings of non-enzyme control.

Gelatinolytic enzymatic activity, expressed as FEI, was determined in three separate experiments using different batches, measured in triplicates $(n=9$ per time point). Data were analyzed using SPSS (IBM Corp, version 22,0, Armonk, NY, USA). Activity of enzymes based on the digestion of the fluorescin tagged gelatin was recorded as fluorescence increase. Kruskal-Wallis with Mann-Whitney U-test was performed using data for all time points (SPSS) $(\alpha=0,05)$.

\section{RESULTS}

The null hypotheses was rejected since gelatinolytic activity in sound deciduous dentin was detected and gelatinolytic activity of its intrinsic enzymes was enhanced when a MMP activator (4-APMA) is used. Sound dentin with 4-APMA demonstrated statistically greater florescence compared to untreated sound dentin $(p<0,05)$. Gelatinolytic activity of sound dentin over 24hour incubation was depicted in Figure 2. The continuous gelatinolytic activity of sound dentin was shown in Figure 3.

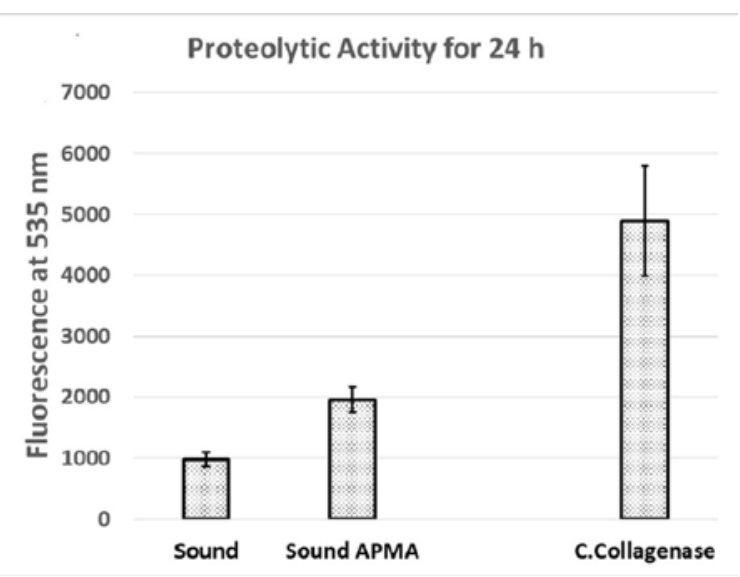

Figure-2 The mean gelatinolytic activity with standard deviation. 


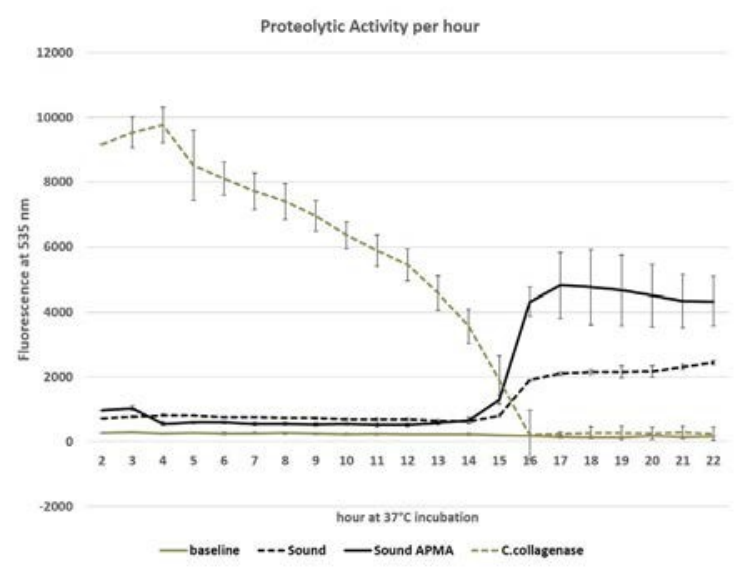

Figure-3 Continuous gelatinolytic activity in $24 \mathrm{~h}$.

\section{DISCUSSION}

The present study investigated the gelatinolytic activity of deciduous sound dentin. A well-known MMP

activator 4-APMA was also tested on deciduous sound dentin to see if the activation is possible on intrinsic gelatinolytic enzymes. The null hypotheses was rejected since gelatinolytic activity in sound deciduous dentin was detected and gelatinolytic activity of its intrinsic enzymes was enhanced when a MMP activator (4-APMA) is used. Thus, findings of this study demonstrated deciduous dentin possess intrinsic enzymatic activity, thus rejecting the null hypothesis.

Within the limitations of the present study, $5 \mathrm{~h}$ exposure to $10 \% \mathrm{PA}$ did not seem to denature the gelatynolytic enzymes in deciduous dentin since their activity was detected and further activated. In permanent dentin, it was shown that $37 \%$ PA short exposure also does not denature the endogenous proteases. ${ }^{19}$ Matrixbound gelatynolitic enzymes for permanent dentin are far more stable to thermal or chemical denaturation than are same enzymes in soluble form. ${ }^{20,21}$ The closeness of the active site of MMPs and cathepsins to their collagenbinding sites ${ }^{22,23}$ explains how stable collagen-bound MMPs are compared to soluble counterparts.

Differences of deciduous dentin structurally and histologically from permanent dentin makes deciduous dentin weaker and thus makes it prone to aggressive caries progression. ${ }^{24}$ Sound permanent dentin harbors latent proteolytic and gelatinolytic enzymes (MMPs) which activate while carious progression begins and MMPs contribute to the destruction in the organic matrix of dentin. ${ }^{6,7,14}$ When the results of the present study is compared to the data exist in the literature for permanent teeth, gelatinolytic enzymes of sound permanent dentin was reported to be present in both (active and inactive) state $^{7}$ while some level of activity in gelatinolytic enzymes were demonstrated in deciduous dentin. However, gelatinolytic enzymes in deciduous sound dentin might be activated during the demineralization process of the dentin powders. ${ }^{19}$ Increase in collagenolytic and gelatinolytic activities of permanent dentin is wellreported for both etch-and-rinse and self-etching bond agents, ${ }^{25}$ and the clinical relevance of the obtained data is having enzymes in active state after acid treatment that may predispose deciduous dentin to the caries initiation. Herein, deciduous sound dentin treated with a stimulator (4-APMA) showed statistically greater gelatinolytic activity compared to untreated sound deciduous dentin, demonstrating the destructive potential of these enzymes under stimulant conditions.

For the permanent teeth dentin, the role of the intrinsic gelatinolytic/proteolytic enzymes are wellknown in caries progression. ${ }^{26}$ However, our knowledge about intrinsic enzymes in deciduous dentin is limited even though there are some recent attempts to locate them in situ. ${ }^{27}$ The methodology used in present study permitted to evaluate enzymatic activity continuously and revealed the presence of gelatinolytic activity first time in sound primary dentin. However, present study lacks to locate and characterize gelatinolytic enzymes in primary teeth dentin. Based on the limitations in our study, characterization of gelatinolytic enzymes and distribution in human primary dentin using immunohistochemical and biochemical assays should be the next step to elucidate their function and identification.

\section{CONCLUSIONS}

Intrinsic enzyme activity and stimulation in deciduous dentin was shown in present study. The potent gelatinolytic activity of sound deciduous dentin and its direct stimulation may aggravate the process in case of a caries initiation. Enzyme inhibitory approach may be the choice to protect deciduous teeth dentin against caries progression.

\section{ACKNOWLEDGEMENTS}

Author would like to thank Prof Ana K. Bedran-Russo and the members of Laboratory of Dental Biomaterials and Interfaces and Departments of Restorative and Pediatric Dentistry at University of Illinois at Chicago, and also like to thank Ms Grace Viana for statistical guidance and review. Author would like to acknowledge National Institute of Dental and Craniofacial Research (grant number DE021040) for the support of present study. 


\section{REFERENCES}

1. Stralfors A. Studies of the microbiology of caries; the acid fermentation in the dental plaques in situ compared with lactobacillus count. J Dent Res 1948; 27 : 576-86.

2. Boyd JD, Cheyne VD, Wessels KE. Is the salivary lactobacillus count a valid index of activity of dental caries? Proc Soc Exp Biol Med 1949; 71: 535-7.

3. Clapper WE, Heatherman ME. Strain differences in oral lactobacilli and the relation to dental caries. J Bacteriol 1949; 58: 261-8.

4. Hojo S, Takahashi N, Yamada T. Acid profile in carious dentin. J Dent Res 1991; 70: 182-186.

5. Kawasaki K, Featherstone JD. Effects of collagenase on root demineralization. J Dent Res 1997; 76:588595.

6. Chaussain-Miller C, Fioretti F, Goldberg M, Menashi S. The Role of Matrix Metalloproteinases (MMPs) in Human Caries. J Dent Res 2006; 85: 22-23.

7. Tjaderhane L, Larjava H, Sorsa T, Uitto VJ, Larmas M, Salo T. The Activation and Function of Host Matrix Metalloproteinases in Dentin Matrix Breakdown in Caries Lesions. J Dent Res 1998; 77: 1622-1629.

8. Hannas AR, Pereira JC, Granjeiro JM, Tjaderjane L. The role of matrix metalloproteinases in the oral environment. Acta Odonto Scandinavica 2007; 65: 1-13.

9. Katz S, Park KK, Palenick CJ. In Vitro root surface caries studies. J Oral Med 1987; 42: 40-48.

10. Chaussain C, Boukpessi T, Khaddam M, Tjaderhane L, George A, Menashi S. Dentin matrix degradation by host matrix metalloproteinases: inhibition and clinical perspectives toward regeneration. Front Physiol 2013; 4: 1-8.

11. Jain A, Bahuguna R. Role of matrix metalloproteinases in dental caries, pulp and periapical inflammation: An overview. J Oral Bio and Craniofac Res 2015; 30: 212-218.

12. Mazzoni A, Mannello F, Tay FR, et al. Zymographic Analysis and Characterization of MMP-2 and -9 Forms in Human Sound Dentin. J Dent Res 2007; 86: 436-440.
13. Santos J, Carrilho M, Tervahartiala T, et al. Determination of Matrix Metalloproteinases in Human Radicular Dentin. J Endod 2009; 35: 686-689.

14. Sulkala M, Larmas M, Sorsa T, Salo T, Tjaderhane L. The Localization of Matrix Metalloproteinase-20 (MMP-20, Enamelysin) in Mature Human Teeth. J Dent Res 2002; 81: 603-607.

15. Vidal CMP, Tjaderhane L, Scaffa PM, et al. Abundance of MMPs and Cysteine Cathepsins in Caries-affected Dentin. J Dent Res 2014; 93:269-274.

16. Stape THS, Tjäderhane L, Tezvergil-Mutluay A, Da Silva WG, Dos Santos Silva AR, da Silva WJ, Marques MR. In situ analysis of gelatinolytic activity in human dentin. Acta Histochem. 2018 Feb;120(2):136-141.

17. Bedran-Russo AK, Pereira PN, Duarte WR, Okuyama K, Yamauchi M. Removal of dentin matrix proteoglycans by trypsin digestion and its effect on dentin bonding. J Biomed Mater Res B Appl Biomater 2008; 85: 261-266.

18. Jackson SL, Vann Jr WF, Kotch JB, Pahel BT, Lee JY. Impact of Poor Oral Health on Children's School Attendance and Performance. Am J of Public Health 2011; 101: 1900-1906.

19. Tezvergil-Mutluay A, Mutluay M, Seseogullari-Dirihan R, Agee KA, Key WO, Scheffel DL, Breschi L, Mazzoni A, Tjäderhane L, Nishitani Y, Tay FR, Pashley DH. Effect of phosphoric acid on the degradation of human dentin matrix. J Dent Res 2013; 92: 87-91.

20. Fernandez S, Geueke B, Delgado O, Coleman J, Hatti-Kaul R. $\beta$-Galactosidase from cold-adapted bacterium: purification, character-ization, and application for lactose hydrolysis. Appl Microbiol Biotechnol 2002; 58: 313-321

21. Berberich JA, Yang LW, Madura J, Bahar I, Russell AJ. A stable three-enzyme creatinine biosensor. I. Impact of structure, function and environment on PEGylated and immobilized sarcosine oxidase. Acta Biomater 2005; 1: 173-181.

22. Roessl U, Nahálka J, Nidetzky B. Carrier-free immobilized enzymes for biocatalysis. Biotechnol Lett 2010; 32: 341-350. 
23. Brömme D, Wilson S. Role of cysteine cathepsins in extracellular proteolysis. In: Extracellular matrix degradation. Parks WC, Mecham RP, editors. Berlin: Springer-Verlag, 2011 edition, p.26.

24. Nör J, Feigal R, Dennison J, Edwards C. Dentin Bonding: SEM Comparison of the Dentin Surface in Primary and Permanent Teeth. Pediatr Dent 1997; 16: 246-252.

25. Bridi EC, Leme-Kraus AA, Basting RT,Bedran-Russo AK. Long-term nanomechanical properties and gelatinolytic activity of titanium tetrafluoride-treated adhesive dentin interface. Dent Mater 2019; 35: 1471-1478.

26. Mazzoni A, Mannello F, Tay FR, et al. Zymographic analysis and characterization of MMP-2 and -9 forms in human sound dentin. J Dent Res 2007; 86: 436-40. Erratum in: J Dent Res 2007; 86: 792.

27. Chibinski AC, Gomes JR, Camargo K, Reis A, Wambier DS. Bone sialoprotein, matrix metalloproteinases and type I collagen expression after sealing infected caries dentin in primary teeth. Caries Res 2014; 48: 312-9. 